\title{
Reagan backs tests in space
}

Washington

PRESIDENT Reagan has decided against renewing talks with the Soviet Union on a treaty to ban weapons for destroying satellites in space. In a report to Congress last week, he said he could not foresee a new arms control treaty for space that would serve the interests of the United States and its allies. And he made it plain that the administration wants to press ahead with tests in space of a controversial new anti-satellite (ASAT) weapon to deter the Soviet Union from using its own more primitive system.

But the president announced last week that the United States would submit to the UN Committee on Disarmament a draft treaty to ban the production, possession and use of chemical weapons.

The president issued the report on satellite weapons in order to release $\$ 19$ million for procurement of the weapon, a homing interceptor launched from beneath the wing of an F-15 fighter (see below). Congress voted the money last year, but put it aside pending a report on plans for negotiating a treaty with the Soviet Union to ban or limit existing and future ASAT systems. Weapons of mass destruction in space are prohibited by the outer space treaty of 1967, which does not, however, constrain the development of weapons designed to destroy satellites.

Technically, publication of the report leaves the administration free to spend the money, even though it has decided against formal negotiations for the time being. The US Air Force has already tested the new weapon within the atmosphere, but tests against targets in space are prohibited by the terms of a Senate stipulation last year that the president must first certify that he is trying "in good faith" to negotiate a ban and that tests are vital to national security.

Last week's report is nevertheless full of arguments against a comprehensive ASAT ban. It says it would be hard precisely to define anti-satellite weapons and virtually impossible to prevent cheating. It says the United States may need an ASAT system in war to shoot down Soviet ocean reconaissance satellites, and that it would be "destabilizing" to leave the Soviet Union in possession of the only operational ASAT; should the Soviet Union shoot down a US satellite during a crisis, the United States, unable to respond in kind, might be forced to escalate instead.

The report has disappointed many in Congress who fear that deployment of the US ASAT will pose such severe verification problems that a future ban on such weapons will be impossible to negotiate.

In 1981 and 1983, the Soviet Union submitted draft treaties to the United Nations banning the use of force in space, and has announced a unilateral moratorium on the launching of any kind of ASAT weapon.
These initiatives are dismissed by the administration as an effort to prevent development of the US weapon. The report claims that Soviet ASAT capabilities include an operational orbital interceptor system, ground-based test lasers with "probable" ASAT potential, the ability to disrupt satellite transmissions electronically and, possibly, to destroy satellites using nuclear armed Galosh anti-ballistic missile interceptors.

Recognizing the strength of congressional sentiment against an arms race in space, the report says the United States is prepared to discuss "a broad range" of space arms control issues in the Committee on Disarmament in Geneva. The administration might also consider negotiating something less comprehensive, such as a ban on weapons that could reach the high altitude satellites that provide early warning of nuclear attack. That may not be enough for Congress, however. Senator Paul Tsongas (Democrat, Massachussetts) is to force an early debate of a resolution calling for a general ban on weapons in space and on weapons designed to destroy objects in space.

Peter David
Research secrecy

\section{Universities in scrap with DoD}

\section{Washington}

RELATIONS between US research universities and the Department of Defense (DoD) are continuing to deteriorate. Cornell University has turned down a $\$ 450,000$ electrical engineering research contract from the US Air Force because it would have imposed an unacceptable degree of secrecy. Meanwhile, the presidents of Massachusetts Institute of Technology, the California Institute of Technology and Stanford University have confirmed that they have written to DoD and to the White House science office saying they cannot accept the publication restrictions proposed in a new DoD directive, DODD 2040.2 (see Nature 29 March, p.389)

Cornell's decision came after months of negotiation with the project sponsor, the Wright Patterson Air Force Base in Ohio. Dr Robert Barker, the university's vicepresident for research, said the Air Force withdrew the contract when Cornell refused to promise to seek prior permission from the Air Force before any technical

\section{Soviet and US approaches to ASAT}

THE Soviet ASAT weapon is an explosive satellite placed in a low-Earth orbit by a modified version of the SS-9 intercontinental ballistic missile. When the satellite approaches its target a small explosive device is detonated, destroying the target with shrapnel.

The US weapon, not yet tested against a target in space, consists of a non-explosive miniature homing vehicle (MHV) designed to destroy its target by impact. The MHV is launched by a small two-stage rocket fired from beneath the wing of a modified F-15 aircraft. An inertial guidance system guides the device to the appropriate location in space, after which the MHV separates from the rocket and closes on the target by means of infrared sensors.

Critics of the US programme complain that, unlike its unwieldy Soviet counterpart, the compact weapon would confound attempts to verify a treaty banning ASATs. The Soviet weapon, by contrast, would have to be launched from a limited number of launch-pads by large and easilyidentified boosters. The Soviet system is believed to have been tested 20 times, most recently in 1982. Six tests of a later version of the weapon, designed to home in on heat emitted by its target, are all believed to have failed.

The Reagan Administration argues that the Soviet weapon poses verification problems of its own. Although the SS-9 is large, the satellite interceptor is small. A covert supply could be maintained even if the
Soviet Union claimed that it had dismantled existing weapons. And it would not take long for the Soviet Union to divert missiles from other tasks to launch the interceptors into orbit. Another problem is that many space technologies not specifically designed to destroy satellites could do so.

$$
\begin{aligned}
& \text { "Gee, Constantin-why didn't } \\
& \text { we think of this before?" }
\end{aligned}
$$

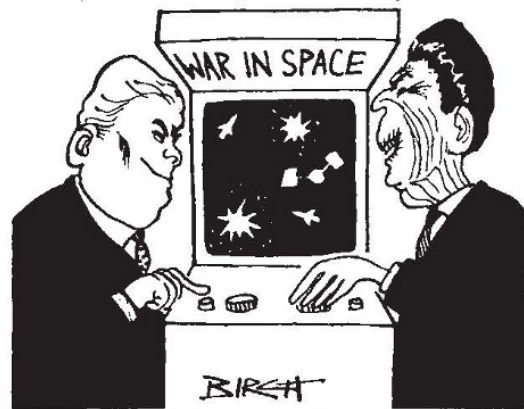

There is no shortage of targets for ASAT weapons. The Soviet Union launches more than 100 civil and military satellites a year, about five times as many as the United States. But US satellites last about five times as long, leaving each side with about 100 active military or military-related satellites in orbit at any time. But the most critical satellites, those that would be used for early warning and control in a nuclear war, tend to be in geosynchronous orbit beyond the reach of the present generation of ASATs. The maximum altitude of both the US and Soviet ASATs is believed to be less than 1,500 miles.
Peter David 
data generated by the three-year project were communicated to foreign nationals. Cornell had already agreed to let the Air Force vet foreign nationals recruited directly for the project. But the university said that since "secret research" was banned at Cornell, it would be impossible to keep foreign nationals out of the project laboratory or to curtail normal scientific conversation within the department of electrical engineering. Last year, thirteen foreign scientists were employed in the department.

The universities hope the Cornell incident and the letter from university presidents will convince DoD that universities are in earnest when they say they would sooner drop defence department contracts than accept an abridgement of their right to publish. When university spokesmen first raised the threat, at a meeting last month of a subpanel of the DoD-University Forum, Dr Edith Martin, the department's UnderSecretary for Research, implied that they were bluffing.

Although her comment could sour the atmosphere at the next full meeting of the forum later this month, the universities are anxious to find some form of compromise with DoD. After the collapse of the Cornell contract, for example, Dr Barker travelled to Washington for extensive talks with $\mathrm{Dr}$ Leo Young, director of research and laboratory management at the Pentagon. $\mathrm{He}$ explained that Cornell and other universities had difficulty in understanding how DoD's category of "sensitive" research differed from classified research - which many universities refuse to undertake.

In a related issue, the research community has responded critically to new draft regulations setting out the circumstances in which the Secretary of Defense can refuse to divulge technical data requested under the Freedom of Information Act. The draft regulations, contained in a DoD directive, DODD 5400.XX, would allow DoD to withhold from the public technical data with military or space applications that could not be exported outside the United States without approval under the Export Administration Act or the Arms Export Control Act.

The regulations have been sharply criticized by the National Science Foundation (NSF), the American Association for the Advancement of Science (AAAS) and the Association of American Universities (AAU). In a letter to DoD, Mr William Carey, executive officer of AAAS, says that by setting out controls for unclassified technical data, the regulations appear to prohibit normal professional communication between scientists working on DoD-sponsored projects and their colleagues in other fields. Dr Robert Rosensweig, president of AAU, has asked DoD to exclude university research from the rules altogether.

Peter David

UK civil service science

\section{Careers congeal on cuts}

CAREER prospects for the mainstream scientists in the British Civil Service have been seriously affected by manpower restrictions, according to a draft study carried out by the Institution of Professional Civil Servants. Although young "high fliers" are still being recognized and given rapid promotion, most scientists in all grades now face a "substantially longer"' wait for promotion than in 1978.

In the past five years, there has been an overall reduction of 11 per cent in the levels of staffing for the main grades and of more than 20 per cent in junior grades. The study, produced by a working group examining the effects of the cuts, concludes that the reductions of up to $\mathbf{7 5}$ per cent in the recruitment of lower grade staff will create serious management problems in the future. But the rate of loss from the service has also decreased, so the rate of promotion on the typical route through the civil sevice grades has markedly declined. Things may not be so bad for all young graduates recruited into the service, however, some of whom can still expect to become Senior Principal Scientific Officers by the age of 33 , with a salary of $£ 15,600$ $£ 20,800$ per year.

Mr Bill Brett, assistant general secretary of the institution, says the fundamental problems of manpower structure will damage both the sciences and the civil service. Many scientists employed by the research councils are on a similar grade system and have been similarly affected by restrictions on manpower and, consequently, on recruitment.

The figures analysed in the latest study may conceal large differences between government departments, an issue the working party sought to investigate. Attempts to do so "have been thwarted by the Treasury's refusal to provide departmental information".

The institution represents 15,500 scientific civil servants and 9,000 scientists employed by the research councils. It has been active in opposing the planned closure of the Letcombe Laboratory in Oxfordshire as part of the current reorganization of the Agricultural and Food Research Council. According to Mr Brett, promotion prospects for those that stay in the council are certain to be badly affected, and about 600 jobs are now expected to be lost. The institution will now be considering a major campaign designed to influence the annual forward planning exercise carried out by the research councils and used as a basis for settling the share-out of the science budget.

Tim Beardsley

\section{Plant conservation}

\section{Rescue plans afoot}

TEN per cent of the world's flora $-25,000$ of 250,000 taxa - are in danger of extinction, according to the World Wildlife Fund and the International Union for the Conservation of Nature and Natural Resources (IUCN). Under the chairmanship of the Duke of Edinburgh, the two organizations last month launched a campaign to encourage worldwide plant conservation.

Funds raised by the World Wildlife Fund will be allocated on the basis of a list of priorities drawn up by IUCN. Apart from a range of in situ conservation activities, for example in the Pleistocene refuge areas of the Cameroon forests, at Korup in India and on the Andaman and Nicobar Islands, the campaign's aim is to create a framework for concerted action and to involve other national and international organizations.

Information is central to this plan. The IUCN conservation monitoring centre at the Royal Botanical Gardens at Kew in London, which already holds details of 13,000-14,000 species of endangered plants, has also set up an additional database (SEPASAT), with help from the overseas charity Oxfam, to store information on economically useful plants from arid areas. There is talk of incorporating data held at the International Board for Plant Genetic Resources (see Nature 8 C) 1984 Nature Publishing Group
March, p.105) into the computer at Kew.

Having surveyed the activities of international organizations as they affect plant conservation, IUCN hopes to involve as many as possible in in situ conservation, for example the World Health Organization for medicinal plants. It will also promote ex situ conservation by widening the scope of the Botanic Gardens Conservation Co-ordinating Body. A micropropagation unit at Kew is successfully rescuing casualties, in particular orchids and ferns. There is still a need for worldwide collaboration to monitor and coordinate garden collections.

Because perhaps 40 per cent of the world's pharmaceuticals come from wild plant sources, the Food and Agricultural Organization has been pooling knowledge on the medicinal properties of trees in selected developing countries. The United National Industrial Development Organization is considering placing small plant-based pharmaceutical industries in developing countries.

A major problem of conservation is law enforcement, and an investigation is being carried out of the international trade in threatened plants and to assess the ability of enforcement agencies in different countries to implement plant trade controls. 